\title{
Emergence of an entrepreneurial opportunity: A case within a Finnish telecommunication international new venture
}

\author{
Teemu Tuomisalo ${ }^{1}$ \\ Published online: 8 June 2019 \\ (C) The Author(s) 2019
}

\begin{abstract}
This article conducts an in-depth investigation of entrepreneurial opportunity recognition in an international new venture (INV) during the time period before the organizational emergence. While doing so, the study applies a strategic orientation (SO) approach that seems to provide the possibility of observing firm activities from multiple perspectives. A qualitative and interpretive method is used for this purpose. The findings of this study support the notion that the phase before organizational emergence is a significant period for entrepreneurial opportunity recognition. Additionally, this study illustrates the reason and processes involved are the same. Firstly, the findings indicate that the initial opportunity recognition and the development throughout this phase rely on the entrepreneurial orientation of the individuals. Moreover, entrepreneurial opportunity results from informationseeking behavior regarding ways to respond to demand. Such a process seems to require a reconciliation of technological and commercial knowledge domains. Secondly, the findings indicate that the context has a distinct role in the opportunity recognition process. In this study, the support of the parent corporation, particularly, seemed to have a significant impact on the initial discovery and subsequent development of entrepreneurial opportunity.
\end{abstract}

\section{Resumen}

Este artículo realiza una investigación en profundidad del reconocimiento de oportunidades emprendedoras en una nueva empresa internacional (NEI) durante el período de tiempo anterior al surgimiento de dicha organización. En base a ello, el estudio aplica un enfoque de orientación estratégica (OE), que ofrece la posibilidad de observar las actividades empresariales desde múltiples perspectivas. Con este propósito, se utiliza un método cualitativo e interpretativo. Los resultados de este estudio apoyan generalmente la idea de que la fase anterior al surgimiento de la organización es un período altamente significativo para el reconocimiento de oportunidades emprendedoras. Adicionalmente, también se busca ilustrar no sólo la razón, sino también los procesos involucrados en dicho reconocimiento. En primer lugar, los resultados indican que el reconocimiento inicial de la oportunidad y el desarrollo a lo largo de esta fase dependen de la orientación emprendedora del individuo/s. Además, la oportunidad emprendedora constituye el resultado del comportamiento de búsqueda de información con respecto a las formas de responder a la demanda. Dicho proceso parece requerir, además, una cierta conciliación de diversos dominios de conocimiento, tanto a nivel tecnológico como comercial. En 
segundo lugar, los resultados indican que el contexto tiene un papel sumamente distintivo en el proceso de reconocimiento de oportunidades. Finalmente, se pone igualmente de manifiesto en este estudio el hecho de que el apoyo otorgado por la empresa matriz tiene un impacto particularmente significativo en el descubrimiento inicial y el desarrollo posterior de la oportunidad emprendedora a través de una NEI.

Keywords International entrepreneurship - Strategic orientation · International new ventures $\cdot$ Entrepreneurial opportunity

Palabras clave Emprendimiento internacional · Orientación estratégica ·

Nuevas empresas internacionales · Oportunidad emprendedora

JEL L26 Entrepreneurship

\section{Summary highlights}

Contributions: This article advances our understanding about the antecedents of entrepreneurial opportunity. The study provides in-depth insights about individual characteristics and contextual features that contributed opportunity recognition during the prelaunch period. In doing so, this study offers novel and significant perspectives for the fields of international entrepreneurship and strategic orientation.

Research questions/purpose: This article conducts investigation of entrepreneurial opportunity recognition during the pre-launch period in an international new venture (INV). While doing so, the study applies a strategic orientation approach. The research question for this article is as follows: How do individuals discover opportunities during the pre-launch period?

Methodology and information: A qualitative and interpretive method is used in a single case setting. The primary data collection method was in-depth interviews conducted with two of the founders of the case company. Moreover, a narrative analysis was applied.

Results/findings: The findings of the study are as follows. Firstly, the findings support the perspective that the pre-launch period represents a significant prerequisite for entrepreneurial opportunity emergence. It was found that this links especially to the characteristics and skills of the individuals, especially reflecting their entrepreneurial orientation. Moreover, it was found that the opportunity discovery was fundamentally information seeking behavior about market imbalances and ways to respond to them. Such a process seems to require a reconciliation of commercial and technological knowledge domains. Secondly, it was found that the context was a significant precondition for the opportunity emergence. In this respect, the most significant elements were the linkage to the MNE and the level of support granted to the project.

Theoretical implications and recommendations: The study offers several in-depth insights about the emergence entrepreneurial opportunity. Firstly, in relation to 
entrepreneurial opportunity theory, this study supports the notion that the pre-launch period is quite significant for entrepreneurial opportunity recognition. Consequently, the findings support the insights that the prior experience and knowledge support opportunity recognition and should therefore be included in the equation. In this respect, an essential feature was the intersection of technological and commercial knowhow which enabled the emergence and subsequent development of the opportunity. In addition, the findings can be linked to the discovery and creation debate where this study support the supplementary insight of the matter and the perspective that the emergence of opportunities occurs in the interaction between individuals and the environment. In addition, the SO perspective adopted in this study offers some very relevant and significant insights. On top of the list is the finding that entrepreneurial orientation can be conceived of as the primary dimension driving the innovationseeking behavior of individuals. Moreover, the market and technological orientation of the individuals were present in the opportunity emergence process. Finally, there are findings that link to the discussion about the role of context; these particularly reflect the institutional features and firm and institutional level events.

Managerial and policy implications and recommendations: The practical findings of this study provide insights for individuals interested in entrepreneurship and innovation. Firstly, in this case, the MNE was ready to allow individuals to continue the project in a spin-off company. Hence, people employed by large multinational enterprises could consider the spin-off option one alternative to start their entrepreneurial careers. Secondly, the recognition and development of entrepreneurial opportunities seems to require openness. Thus, entrepreneurs and entrepreneurs-to-be need to keep their minds open and to be ready to acquire feedback to recognize and develop entrepreneurial opportunities further.

Limitations: The limitations of this study are as follows. Firstly, findings are based on material involving one company and therefore over-generalization should be avoided. Thus, further research is required in different industries. Secondly, the interview material was retrospective and cross-sectional. Hence, real-time and longitudinal studies are required to provide in-depth findings of entrepreneurial opportunity development.

\section{Introduction}

"The process of how ideas come into existence, is, an inherent aspect of entrepreneurial narrative" (Gartner 2007).

The manner in which entrepreneurs recognize opportunities is a central interest of entrepreneurship research (Bergh et al. 2011; Hayton and Cholakova 2012). However, it seems that we still have plenty to explore to explain thoroughly how entrepreneurial opportunities are recognized. In this respect, one of the areas requiring further research is the period before the official establishment of a firm. The reason is that preparations 
of international small and medium-sized enterprises (SMEs) can begin well before the firms are set up (Hewerdine and Welch 2013). Consequently, it has been suggested that researchers should focus on activities which take place before the establishment of a firm (Hewerdine and Welch 2013) (henceforth described by the term pre-launch period). Moreover, recent studies have suggested that we could further investigate the antecedents of entrepreneurial opportunity recognition and exploitation to explain the opportunity phenomenon in more detail (Kuckertz et al. 2017). This could be achieved, for instance, by investigating the role of prior knowledge (George et al. 2016) and prior experience (Haynie et al. 2009) in relation to entrepreneurial opportunity recognition.

Accordingly, the aim of this research is to conduct an in-depth investigation of opportunity emergence during the pre-launch period in an INV. For this purpose, strategic orientation (SO) approach seems suitable for fulfilling the objectives of this study. This approach enables the investigation of firm-based activities from several aspects, such as the market, technology, and entrepreneurial orientation (Hakala 2011). Moreover, in previous studies, SO has already been found to support opportunity recognition (Kakapour et al. 2016), the emergence of radical innovations (Kocak et al. 2017 ) and the use of innovation-based strategies as competitive advantage (Knight and Cavusgil 2004) of SMEs. Additionally, in doing so, this study can offer novel and significant perspectives for SO literature as more knowledge is required regarding the influence of prior experience on strategic orientation dimensions (Presutti and Odorici 2018). However, this study focuses on the individual entrepreneurs and their conception of opportunity emergence (Dimov 2011). Therefore, based on these research gaps and future research suggestions from previous studies, the research question for this article is as follows: How do individuals discover opportunities during the pre-launch period?

The abovementioned research question is answered through a study conducted using a qualitative and interpretive method in a single case setting. This approach emphasizes the individual interpretations and enables in-depth descriptions of the studied phenomenon (Walsham 1995). Moreover, a narrative analysis is applied, supporting the indepth focus of the study (Langley 1999). The case company (codenamed) is Wireless Telegraph Company (henceforth abbreviated to WTC), which is an INV operating in the telecommunication sector. WTC was established in 2012, but its entrepreneurial opportunity originated in January 2010 when it was an independent business unit within a multinational enterprise (MNE). This research focuses on the period (20102012) when entrepreneurial opportunity was developed as part of the MNE. The research material has been collected from two of the founders who have been working on the opportunity from the beginning. A discussion, below, on the theoretical framework of the study is followed by the description of its aims and methodology. Subsequently, the article goes on to introduce the empirical findings, followed by the discussion section and future research implications.

\section{Theory and literature review}

\section{Entrepreneurial opportunity}

Opportunity is a central element in the field of International Entrepreneurship (IE). This research focuses especially on the international aspect, as Oviatt and McDougall (2005) 
define IE as follows: "the discovery, enactment, evaluation, and exploitation of opportunities - across national borders - to create future goods and services." In INVs, the opportunities are closely connected to the individual founders: "who see opportunities from establishing ventures that operate across national borders. They are 'alert' to the possibilities of combining resources from different national markets because of the competencies (networks, knowledge, and background) that they have developed from their earlier activities." (Phillips-McDougall et al. 1994, p. 470). The recent empirical findings support such a notion. For instance, a study by Hannibal et al. (2016) found that opportunity recognition by university-based INVs was closely connected with the abilities and motivation of the individuals. Nevertheless, there is still plenty to do relating to this topic. For instance, there are two primary approaches which have been conceived to increase understanding about entrepreneurial opportunity phenomena. Firstly, there is the insight that we should consider the period before the organizational emergence in our studies (Hewerdine and Welch 2013) and investigate the antecedents of opportunity recognition (Kuckertz et al. 2017). For instance, a recent review by George et al. (2016) suggests that the investigation of prior knowledge is a significant avenue for future research. Secondly, there is the contextaware perspective. This implies that we should acknowledge and investigate further how context affects the conditions for opportunities (Reuber et al. 2017). The context awareness in question suggests that the situational features can influence the occurrence of opportunities; that is to say, opportunity recognition may be affected by (i) country-specific, institutional, and industry-related features, (ii) sociocultural differences and the temporality of time, and (iii) individual, firm, and institutional level events (Reuber et al. 2017).

Entrepreneurial opportunities are essentially new products, services, raw materials, market, or organizing methods that form new means-ends relationships (Eckhardt and Shane 2003; Shane and Venkataraman 2000). These new means-ends can be achieved by satisfying market needs (means) or creating new demand (ends) or by doing both (Eckhardt and Shane 2003, p. 336). Central to the existence and identification of opportunities is the knowledge that individual entrepreneurs possess regarding market imbalances (Eckhardt and Shane 2003). Thus, the opportunity discovery process can be considered an active search behavior (Mainela et al. 2014) and alertness (Kuckertz et al. 2017) for innovative products or services which respond to the market imbalance between supply and demand. Moreover, it seems that opportunities are often discovered in circumstances in which contrasting knowledge domains (Hansen et al. 2011) and knowledge asymmetries meet (Corbett 2005; Eckhardt and Shane 2003).

A very central topic of current opportunity-related research has been the debate on whether opportunities are discovered or created (George et al. 2016; Suddaby et al. 2015). Thus, discovery and creation perspectives are considered separate theories of entrepreneurial opportunity. These theories differ in terms of how they conceive the nature of opportunities, the role of entrepreneurs, and the process of exploitation of the opportunity (George et al. 2016). The discovery perspective considers opportunities to be existing in the environment objectively (Suddaby et al. 2015) and independently of the entrepreneur (George et al. 2016). This viewpoint emphasizes the interaction between the environment and individual entrepreneurs, which may lead to the recognition of market imbalances (Suddaby et al. 2015). The creation perspective views entrepreneurial opportunities as endogenous acts in which entrepreneurs create opportunities through their creative imagination and social skills (Suddaby et al. 2015). In other words, based on the creation perspective, opportunities do not exist independently 
but the entrepreneur must create them (George et al. 2016). This viewpoint emphasizes the individual entrepreneur's ability to realize previously non-existent and alternative social and economic arrangements from the environment (Suddaby et al. 2015).

Nevertheless, some recent studies have suggested that the debate regarding whether opportunities are discovered or created may be unnecessary, as there are elements of truth in both perspectives (Renko et al. 2012). This perspective holds that individuals spot opportunities from the objective environment, based on their subjective perceptions of how to address them, as accurately as possible (Renko et al. 2012, p. 1246). Oyson and Whittaker (2015) further explore this matter. These authors suggest that discovery and creation are two separate phases in the opportunity actualization process. Discovered opportunities are the output of the entrepreneurs' imagination, which has not yet exposed to the external environment. Hence, they are still "broad, vague or incomplete and not ready for exploitation" (Oyson and Whittaker 2015, p. 329). In order to be exploited, they need to be "transformed into concrete, entrepreneurial opportunities- in other words, 'created'." (Oyson and Whittaker 2015, p.329). Thus, these authors take the ontological stand that the discovered opportunities are only potential ones, until they are actually transformed into opportunities (Oyson and Whittaker 2015).

To conclude, entrepreneurial opportunity is a significant phenomenon in the field of IE. Nevertheless, it is also a topic which requires substantial further research, so that we can accurately describe how and why entrepreneurial opportunities arise. Hence, this article concentrates on one of the key development areas, namely the period before organizational emergence (Hewerdine and Welch 2013). Accordingly, it seems that we should shift our focus from the ontological debate to investigating how individuals recognize entrepreneurial opportunities from the environment based on their perception (Renko et al. 2012). Therefore, opportunity recognition has been strongly linked with the manner of responding to market need (Kuckertz et al. 2017; Mainela et al. 2014). Moreover, opportunity recognition also seems to be linked intricately to the abilities and motivations of the individuals (Hannibal et al. 2016), and this is supported by the interconnection of different levels (Corbett 2005; Eckhardt and Shane 2003; Hansen et al. 2011).

This study implements the strategic orientation (SO) approach because this supports the objectives of this article and provides several advantages related to the aforementioned aspects. Firstly, the SO approach provides several aspects to investigate entrepreneurial opportunity recognition such as the market, technological, and learning orientations (Hakala 2011). Secondly, previous studies have found that SO supports opportunity recognition (Kakapour et al. 2016) and links to the radicality of innovation (Kocak et al. 2017) and how innovation-based strategies are applied as competitive advantage in SMEs (Knight and Cavusgil 2004). These insights are beneficial for this article. Thirdly, by applying the SO approach, this article provides novel insights that can be used to promote the SO discipline. Consequently, through this study, it is possible to promote this field by studying how experience affects different dimensions of SO which is one of the research gaps (Presutti and Odorici 2018). In the following section, the principles of the SO approach and its use in SME-related research have been discussed in more detail.

\section{Strategic orientation}

Basically, SO can be considered a set of "principles" that steer the activities of a firm to improve its organizational performance (Balodi 2014; Hakala 2011). According to a 
systematic review by Hakala (2011), there are four main dimensions applied regularly in SO research: the market, entrepreneurial, learning, and technology orientation. According to this comprehensive review, market orientation represents the external features of the organization, reflecting its awareness of customers and competitors and the exploitation of the market knowledge. Technology orientation reflects the firm's desire to create customer value and increase competitive advantage by creating new technologies, products, and services. Entrepreneurial orientation reflects the innovative, proactive, and risk-taking behavior adopted by the organization. The learning orientation reflects the organization's overall capability to turn the recognized opportunities into actions (Hakala 2011).

The SO research carries implications for entrepreneurial opportunity theory as well. Therefore, especially, the "outward-looking" features of SO seem to play a significant role in SMEs which provide the "...market knowledge and lead into new decisions to explore and exploit opportunities for innovation." (Kocak et al. 2017, p. 262). Hence, the entrepreneurial orientation manifests in the proactive and opportunity-seeking conduct of entrepreneurs, while discovering and introducing new technological solutions (Odorici and Presutti 2013). Moreover, Kickul and Gundry (2002) contend that entrepreneurs with "prospector" type characteristics are more likely to recognize opportunities for developing new products and markets (Kickul and Gundry 2002). In the field of IE, SO is linked with the internationalization process (Ruokonen and Saarenketo 2009) and international performance (Jantunen et al. 2008) of SMEs. At the individual level, it seems to be linked to the characteristics of the entrepreneurs and the innovation efficacy of the firm (Cooper et al. 2016). Innovation seems to be central to rapidly internationalizing ventures as well. A study by Knight and Cavusgil (2004) concluded that early internationalization and the international performance were related to the innovative nature of the Born Globals (BGs). In their view, these are companies that "...from or near their founding, seek superior international business performance from the application of knowledge-based resources to the sale of outputs in multiple countries." (Knight and Cavusgil 2004, p. 124). Even though these authors do not refer directly to SO literature, they found that the (international) entrepreneurial and marketing orientation of BGs drives them to develop high-quality goods and innovation-based strategies which are the primary prerequisites for international success (Knight and Cavusgil 2004).

Based on the literature review, it seems that $\mathrm{SO}$ is a functional approach to investigating the emergence of entrepreneurial opportunity. In terms of this field of research, entrepreneurial opportunity recognition is a result of the unprovoked opportunity-seeking behavior of individuals. Moreover, in relation to IE, it stands out through its emphasis on innovation, which is considered one of the primary competitive advantages of rapidly internationalizing SMEs. Overall, SO offers a versatile set of perspectives to investigate opportunity-related activities in SMEs.

\section{Methodology}

The objective of this study is to investigate the emergence of entrepreneurial opportunity during the pre-launch period, by focusing on the knowledge-related aspect (see, e.g., Eckhardt and Shane 2003; Kuckertz et al. 2017). While doing so, the study applies the SO approach which enables investigation of how individual characteristics 
influence entrepreneurial opportunity (see, e.g., Kickul and Gundry 2002; Odorici and Presutti 2013). In addition, this study links entrepreneurial opportunity with innovation, which is a central aspect in the field of IE (Coviello and Tanev 2017; Hewerdine and Welch 2013) and SO-related research (Gatignon and Xuareb 1997; Knight and Cavusgil 2004).

This study tackles the task by applying a qualitative methodology, which is considered a promising alternative to advance understanding about entrepreneurial opportunity (George et al. 2016). Moreover, this is an interpretive case study, highlighting as it does the individuals' interpretation of the phenomenon (Walsham 1995). Thus, the study provides a detailed description of the studied phenomenon by revealing its real-life dynamics (Dyer Jr. and Wilkins 1991). The single case setting further enhances the indepth investigation of the topic (Dyer and Wilkins 1991). Overall, the aim of this article is not to generalize (McGaughey 2006) or to present an extreme case for theory (Eisenhardt and Graebner 2007) but to provide an extensive description of what is happening in this particular context (Walsham 1995; Welch et al. 2011). Hence, it is anticipated that this research will offer new insights in the subject of entrepreneurial opportunity and SO and provide novel future research avenues for both streams of research.

\section{Data collection and analysis}

This is a cross-sectional and retrospective study (see Fig. 1). The observation period covers the timeframe from the initial opportunity discovery in January 2010 until the establishment of the case company in August 2012. The primary data collection method was in-depth interviews conducted with Mike and Tom (codenamed), who have worked on the opportunity from the beginning till this day (as of December 2018). The interview method was selected because it emphasizes individual interpretations of the actions and events related to the phenomenon (Walsham 1995, p. 78). Moreover, the use of open-ended interviews may raise novel insights and, in doing so, promote theory building of the phenomenon (Suddaby et al. 2015). The data collection and analysis are discussed in greater detail in the following sections.

The primary data comprised in-depth interviews conducted with Mike and Tom. The in-depth interview with Mike took place in April 2016, and Tom was interviewed later in December 2016. Both were interviewed separately, and the interviews took place in the office space of WTC, which was situated at that time in a metropolitan area of Finland. The duration of the interview with Mike was $86 \mathrm{~min}$, whereas Tom's interview was for $101 \mathrm{~min}$; the interviews were tape recorded and transcribed into word documents. Interview questions were related to (i) the personal education and work histories before the initial opportunity discovery, (ii) motives for working with the opportunity, (iii) the description of the events and activities during the pre-launch period, and (iv) the current state of the entrepreneurial opportunity at the time of the interview. In addition, these interviews included informal discussions on entrepreneurship and the innovation. Notes were also taken during the interviews, for instance, on the general atmosphere of the interviews and the mood of the interviewees.

The secondary data comprised the introductory interview, as well as follow-up interviews, an email discussion, and social media publications. The introductory interview was conducted with Mike. This was partly a negotiation about participating in the research project and partly an introduction to WTC and their innovation initiatives and occurred in 


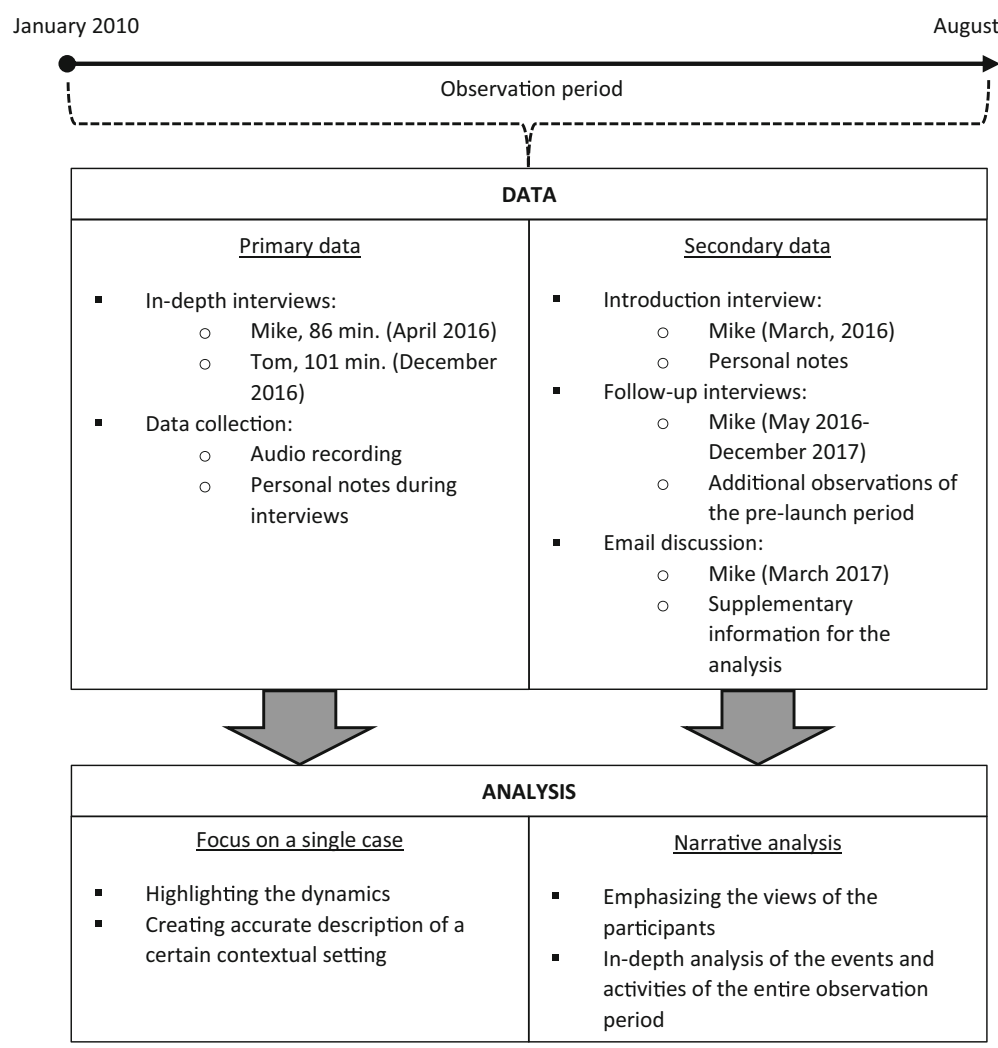

Fig. 1 Research design

March 2016. This involved no prior questions and was very informal in nature. Only personal notes were made during this event. Moreover, the researcher resorted to followup interviews (conducted during 2016-2017), whenever issues related to the emergence of the opportunity arose. This happened regularly when Mike evaluated the progress of innovation. In the case of this article, only Mike's interviews were applied in the analysis, as he was the only one who had been involved in the pre-launch period. Moreover, a comprehensive email discussion was carried out with Mike during the analysis, with more specific questions about entrepreneurial opportunity emergence. Social media observation included the blog published by the case company and Mike's activity on LinkedIn.

The analysis focused on a single case company, seeking to obtain an in-depth description of a particular social setting (Dyer Jr. and Wilkins 1991). In other words, the objective was to highlight the dynamics of the phenomenon and attain an accurate description of the aspects of this carefully restricted context (Dyer Jr. and Wilkins 1991). The data analysis followed the ideas of Dawson and Hjorth (2012) regarding narrative analysis. In the first phase, all the critical events and activities contributing to the entrepreneurial opportunity were summarized. This was accomplished by constructing a "multivoiced story" of both the interviewed individuals. The second phase included an in-depth analysis of how these observed events and activities contributed to entrepreneurial opportunity. In the third phase, the complete 
story of the entrepreneurial opportunity emergence was written. The fourth and final phase of the analysis involved the construction of a "third story" in which the findings were compared with the theoretical framework of this study (Dawson and Hjorth 2012). This implies that special attention was paid to observing the role of prior experience (Haynie et al. 2009 ) and prior knowledge (George et al. 2016) in opportunity emergence. In relation to the SO literature, the analysis focused on how the SO of the individuals affected their ability to recognize opportunities (Kakapour et al. 2016).

\section{Findings}

The case company (codenamed Wireless Telegraph Company, abbreviated WTC), is a Finnish INV that operates in the telecommunications industry. The selection criterion of the case company followed Oviatt and McDougall's (1994, p. 49) definition of an INV: "...that, from inception, seeks to derive significant competitive advantages from the use of resources and the sale of outputs in multiple countries". These conditions were met in the following way. WTC was established officially in August 2012, as a spin-off from an MNE where it had been an independent project since January 2010. WTC began to seek overseas access, immediately after establishment. Therefore, WTC has been engaged in several development projects of various mobile network solutions in North America, Central America, South America, Scandinavia, Continental Europe, South Asia, Middle East, South Africa, and Eurasia since its establishment.

Nevertheless, the innovation was based on an opportunity that emerged during the pre-launch period (2010-2012). During this time, the team created a prototype of a telecommunication solution for fixed networks which was soon changed into a mobile network solution. These phases, including the critical events and activities related to entrepreneurial opportunity emergence and development (see Fig. 2), are described in detail in the following section.

The people interviewed (see Table 1) for this research are Mike and Tom (codenamed) who have been part of the entrepreneurial opportunity since its commencement in January 2010. Mike is an engineer belonging to a Nordic country and has worked in various positions in the MNE from 1997 to 2012. The job description included management of several product launches, similar to what became the entrepreneurial opportunity for WTC. Moreover, his responsibilities included working with various innovations and cooperation with external technology startups. In addition, business trips and stays abroad were common as Mike was stationed in North America, South Asia, and Central Europe during his career. He founded WTC in August 2012 and has been working full time on it since then.

Tom, hailing from southern Europe, has a $\mathrm{PhD}$ degree in software and computer sciences. He started working for the MNE in 2009 and had various tasks there until the end of 2017. The job description included software engineering and management work. Moreover, he participated regularly in the innovation competitions held in the MNE. During his employment, Tom lived in North America and Central Europe, and the constant traveling around the world was a part of his job description. He met Mike for the first time during the innovation competition held in January 2010 and has been involved in the opportunity since then. Currently, he is a small-scale investor in WTC where he works full time on technological development. 


\begin{tabular}{|c|c|c|c|}
\hline \multicolumn{4}{|c|}{ FINDINGS } \\
\hline \multicolumn{2}{|c|}{$\begin{array}{l}\text { I) THE INITIAL OPPORTUNITY DISCOVERY } \\
\text { Fixed network solution prototype }\end{array}$} & \multicolumn{2}{|c|}{$\begin{array}{l}\text { II) TRANSFORMATION INTO A MOBILE SOLUTION } \\
\text { Conceptual idea of mobile network solution }\end{array}$} \\
\hline $\begin{array}{l}\text { Role of context: } \\
\text { i) Starting point for entrepreneurial opportunity } \\
\text { stemmed from EC proposal and idea competition } \\
\text { held in the MNE } \\
\text { ii) Support by the MNE contributed to the } \\
\text { entrepreneurial behavior of the individuals }\end{array}$ & $\begin{array}{l}\text { The characteristics and skill of individuals: } \\
\text { i) Encounter of technological and commercial } \\
\text { knowhow } \\
\text { i) Independent and innovation-seeking behavior of } \\
\text { individuals }\end{array}$ & $\begin{array}{l}\text { Role of context: } \\
\text { i) MNE corporate strategy as mobile actor within } \\
\text { the industry } \\
\text { i) Level of support by the MNE collapsed which had } \\
\text { effect on innovation implementation but did not } \\
\text { hinder the entrepreneurial orientation of the } \\
\text { individuals }\end{array}$ & $\begin{array}{c}\begin{array}{c}\text { The characteristics and skill of individuals: } \\
\text { i) Encounter of technological and commercial } \\
\text { knowhow }\end{array} \\
\text { i) Independent and innovation-seeking behavior of } \\
\text { individuals }\end{array}$ \\
\hline \multicolumn{4}{|c|}{ IONS F } \\
\hline ENTREPRENEURIAL OP & PORTUNITY LITERATURE & STRATEGIC ORIENTATIC & ION APPROACH \\
\hline $\begin{array}{l}\text { Illustration of individual expertise and knowho } \\
\text { discovery: } \\
\text { i) Various knowledge dimension needed for opp } \\
\text { Shane, 2003; Hansen et al., 2011) } \\
\text { - Intersection of technological and comme } \\
\text { Illustration of how and why context affects en } \\
\text { i) Institutional features and characteristics (Reu } \\
\text { - Level of support by the MNE have a sign } \\
\text { - MNE corporate strategy affected entrep } \\
\text { i) Institutional-level event (Reuber et al., 2017) } \\
\text { - EC technology proposal supported the in } \\
\text { i) Firm-level event (Reuber et al., 2017) } \\
\text { - Idea competition held by the MNE suppo }\end{array}$ & $\begin{array}{l}\text { w contributing to entrepreneurial opportunity } \\
\text { ortunity recognition (Corbett, 2005; Eckhardt \& } \\
\text { rcial expertise } \\
\text { repreneurial opportunity: } \\
\text { ber et al., 2017) } \\
\text { ficant impact on entrepreneurial opportunity } \\
\text { eneurial opportunity development } \\
\text { tial discovery } \\
\text { rted the initial discovery }\end{array}$ & $\begin{array}{l}\text { Illustrating the main driver of opportunity recognitio } \\
\text { i) Entrepreneurial orientation is the key feature in opp } \\
\text { Gundry, 2002; Odorici \& Presutti, } 2013) \\
\text { - Willingness to work among independent projec } \\
\text { behavior } \\
\text { Illustration that the market and technological orienta } \\
\text { opportunity recognition: } \\
\text { i) Market orientation (Hakala, 2011) } \\
\text { - Knowledge about the industry and customer ne } \\
\text { the teleoperators) } \\
\text { - Understanding the corporate alignment as a mo } \\
\text { - Knowledge about the industry and customer ne } \\
\text { sector for the solution) } \\
\text { i) Technological orientation (Hakala, 2011) } \\
\text { - Technological knowhow to create and modify } \\
\text { demand } \\
\text { Illlustration of how context affects so: } \\
\text { i) The support of MNE was linked to the entrepreneuri, } \\
\text { Kickul \& Gundry, 2002; Odorici \& Presutti, 2013) } \\
\text { - Support contributed to entrepreneurial orienta } \\
\text { - Lack of support had limited effect on entrepren }\end{array}$ & $\begin{array}{l}\text { on: } \\
\text { portunity emergence (Hakala, 2011; Kickul \& } \\
\text { cts and the presence of innovation seeking } \\
\text { tation of the individuals were present in } \\
\text { need (Network capacity handling challenges of } \\
\text { nobile actor } \\
\text { heed (More demand in the mobile network } \\
\text { opportunity according to the realization of } \\
\text { rial orientation of the individuals (Hakala, 2011; } \\
\text { ation of the individuals } \\
\text { neurial orientation }\end{array}$ \\
\hline
\end{tabular}

Fig. 2 Entrepreneurial opportunity emergence and development

\section{The initial discovery of the entrepreneurial opportunity}

The starting point for this entrepreneurial opportunity stemmed from an idea competition held in the MNE in 2009. The task was to create a new line of business for the MNE, by exploiting new technologies. Here, a separate team ran into a European Commission proposal which suggested that a certain technology could be employed in the telecommunication sector. The result was a conceptual idea about how this

Table 1 Presentation of the interviewees

\begin{tabular}{|c|c|c|c|c|c|}
\hline & $\begin{array}{l}\text { Educational } \\
\text { background }\end{array}$ & Work history in MNE & $\begin{array}{l}\text { Entrepreneurial } \\
\text { activity in MNE }\end{array}$ & $\begin{array}{l}\text { Role in opportunity } \\
\text { recognition }\end{array}$ & $\begin{array}{l}\text { Motivation for } \\
\text { entrepreneurship }\end{array}$ \\
\hline Mike & $\begin{array}{l}\text { Automa- } \\
\text { tion } \\
\text { engineer } \\
\text { - Bachelor's } \\
\text { degree }\end{array}$ & $\begin{array}{l}\text { - } 1997-2013 \\
\text { - Program manager, } \\
\text { product } \\
\text { management }\end{array}$ & $\begin{array}{l}\text { - Several } \\
\text { independent } \\
\text { product } \\
\text { launches }\end{array}$ & $\begin{array}{l}\text { - Commercially oriented } \\
\text { knowhow } \\
\text { (industry-market } \\
\text { interface) }\end{array}$ & $\begin{array}{l}\text { - Strong } \\
\text { attachment to } \\
\text { the } \\
\text { opportunity } \\
\text { - Long-term } \\
\text { dream to es- } \\
\text { tablish own } \\
\text { software firm }\end{array}$ \\
\hline Tom & $\begin{array}{l}\text { - Computer } \\
\text { science, } \\
\text { PhD }\end{array}$ & $\begin{array}{l}\text { - } 2009 \text { onwards } \\
\text { - Software engineer, } \\
\text { team leader, senior } \\
\text { architect, system } \\
\text { architect }\end{array}$ & $\begin{array}{l}\text { - Participating in } \\
\text { several } \\
\text { innovation } \\
\text { competitions }\end{array}$ & $\begin{array}{l}\text { - Technological } \\
\text { knowhow (hands-on } \\
\text { knowledge about the } \\
\text { innovation) }\end{array}$ & $\begin{array}{l}\text { - Strong } \\
\text { attachment to } \\
\text { the } \\
\text { opportunity } \\
\text { - Desire to create } \\
\text { new things }\end{array}$ \\
\hline
\end{tabular}


technology could be applied as a network solution which was then forwarded to a subsequent development stage that was the innovation competition.

The innovation competition was a three-month technology development project that took place in Northern America in January 2010. The objective was to create business prototypes for the MNE based on the conceptual level ideas that originated from the previous event. Mike decided to participate in this project and was assigned a fivemember team to transform the idea into a prototype. The team consisted of Mike, Tom, and three other employees originating from the Baltics, Central Europe, and South Asia. The premise seemed to be excellent for such a project. Mike and Tom stated that it was the most productive and pleasant period in the entire history of their work on the opportunity, including the time after it became their own business. Consequently, the team was given total independence to proceed with the project which Mike described as "working already in a startup mode." Moreover, it seemed that the setting was appropriate to motivate the participants on site; Tom describes this as follows: "And people who were willing to do some stuff. It was fun. It was the reality of multicultural teamwork in a multicultural team. As a team, it was... I used to be a researcher previously, it was more like alone work. You know about that." (Tom).

The conceptual idea was based on a solution that the network capacity could be transmitted to the network operators. Mike described how during the innovation competition they: "...took it then step or two further..." (Mike, Email 2017). Based on their personal experience, Mike and Tom knew that the allocation of fixed network capacity between the operators at the time was done manually. They realized that there was an opportunity to automate this process. Hence, the team began working on a software solution that would enable this. The task was executed under Mike's leadership as line manager, and the actual implementation was mostly possible due to Tom and the rest of the team's technological knowledge and coding.

The prototype was finished in March 2010, after 3 months of work. As a result, the team was rewarded with " $a$ half of funding", meaning that the project was relocated in Central Europe for a year. However, only Mike and Tom were willing to follow the project there. Thus, the rest of the team in Central Europe were new members: one originating from Central Europe and the rest from the Middle East. The relocation caused a serious setback to the opportunity development and that year was considered unsuccessful. For instance, Tom stated that it was not " $a$ very good year". When asked why, he described that the general atmosphere within the MNE was changing at that time, especially because it was not investing in the innovation development anymore. Moreover, due to the reduced availability of resources, the internal competition with the other teams at the site turned critical. Tom described this competition as a sort of battle for survival such that the teams were fighting for the budget by downsizing the others; as Tom describes it, "... it also seemed, if he killed our project, he will get the budget. Simple as that." (Tom).

Similarly, Mike described that the time in Central Europe "was bad." The first reason according to him was that the team they had in North America was dispersed as most of the team simply did not want to be relocated to Europe. This disruption meant that a significant part of the knowhow for the project was lost. The second issue according to him was the incompatibility of the new team members. The team in Central Europe experienced strong cultural clashes, making it nearly impossible to make any technological advancements in such a situation. Mike describes this as follows: "There was maybe like a professional experience that there can be too much 
diversity [within a team]" (Mike, Follow-up interview \#11). Nevertheless, the intellectual efforts of Mike and Tom eventually paid off at the end of the project as, "During this time, the decision was made that we need to start watching mobile network" (Mike, Follow-up interview \#11). Essentially, this meant a new direction for the opportunity. With this in their pocket, they were sent to a new location in the Middle East in the summer of 2011.

The findings (see Fig. 2) related to the initial discovery of the opportunity indicate that the premise for the innovation was set before any actual work had been done. In this study, the starting point can be traced to the proposal by the European Commission, which initiated the chain of events leading to the initial opportunity discovery. Moreover, the findings indicate that the support by the MNE was crucial for the opportunity emergence. At this stage, this contributed significantly to the entrepreneurial behavior of individuals. With respect to the research setting, these findings support the insight that context can have a significant impact on entrepreneurial opportunity recognition (Reuber et al. 2017). In this case, the findings demonstrate that the support of MNE was especially linked to the entrepreneurial orientation of individuals (Hakala 2011). Moreover, the findings support the insight that entrepreneurial orientation is crucial to discovering new technological solutions (Odorici and Presutti 2013) and that the prospector type strategic orientation promotes opportunity recognition (Kickul and Gundry 2002). In addition, the findings indicate that the collision of different professional expertise has significantly impacted opportunity recognition. This was especially linked to the intersection of technological and commercial knowledge; hence, this finding validates the insight regarding contrasting knowledge domains (Hansen et al. 2011) and knowledge asymmetries (Corbett 2005; Eckhardt and Shane 2003) contributing significantly to the opportunity discovery process. If these findings are compared with SO literature, these are similar to technological and market orientation (Hakala 2011). These findings are further discussed in Sect. 5, which provides an in-depth analysis of how these influenced the initial opportunity discovery and the implications of these findings in relation to the research setting of this article. However, before this, another significant phase of opportunity emergence during the pre-launch period has been explored in the following section.

\section{Transformation into a mobile network solution and the aftermath}

From the Central European posting, the project was relocated to the Middle East in the summer of 2011. Now, the team consisted of Mike, Tom, and a salesman from their previous location in Central Europe, whereas the rest were new, local members from the site. This time the rearrangement of the team was considered a success as the new members turned to be: "Good engineers and great persons." (Tom). Moreover, the new members confirmed the insight that innovation could be applied within mobile networks. Thus, it was decided to switch the opportunity and its development to a mobile network solution. The reason for the switch was two-fold. Firstly, it was evaluated that the innovation had more commercial value in the mobile networks. Secondly, there was the realization that this was more aligned with corporate strategy as the MNE was a high-profile mobile actor within the telecommunication industry. Thus, the end of 2011 proved to be a significant turning point for the entrepreneurial opportunity. The team decided to focus on developing the wireless network solution instead of the original idea of fixed networks. This deviated from the previous approach in that the mobile 
solution was more about differentiating the network capacity between different customer groups and according to their preferences, whereas earlier it involved guaranteeing the fixed broadband quality between the teleoperators. Nevertheless, the original opportunity was not abandoned but was put aside for the time being to be executed, as Mike described it, "When the world is ready for it...".

However, the project did not get further support from the MNE which was cutting down its operations and laying off people at the time. Therefore, despite the team's best efforts, no decision maker was ready to endanger their employment in the MNE by allocating resources for a product which was still in its early developmental phase. For the opportunity development, it meant that no significant technological advancements could occur. Mike describes the stand-off as follows:

"In the Middle East there was a technologically really capable team, but it was maybe in a sort of early stage. In a sense it was annoying that it would have been great to continue, because we could have developed it into a peak team, but they [decision makers] were in a sort of double-lock mode, and who had gone through a couple of codeterminations, it ended so that I had to dismiss these people, before [dismissing] myself." (Mike, Follow-up interview \#11)

During this time, the team realized that things were no longer the same in the MNE. Tom mentioned that the MNE was not investing any more in the implementation of innovation as it had done previously in its history:

"Yeah if you think about the golden age of MNE, they were creating new stuff. And suddenly, no. The last ten years they never created something new. They just evaluate the things, like $3 G, 4 G$, data. But not something new, something changing stuff...This is something that, you know, it's the lifecycle. It must be done, because you cannot be at the top all the time." (Tom)

Regardless, Mike and Tom at this stage were willing to continue working on the opportunity even on their own. Hence, the initial discussions about spinning off the company took place in the spring of 2012 between Mike and Tom. Nevertheless, the idea of establishing a company was something that Mike especially held dear. As Tom mentioned in the interview, "No, I think in the planning process, about being a company, it was only Mike" (Tom). Moreover, Mike's motive of launching his own business seemed to have taken root years ago as he had been collaborating with several startups. Mike got acquainted with various innovations while working in the MNE and was impressed by the capabilities of these firms, as he describes:

"During the time in the MNE. And well, that of course many. Many firms approached us then and I got familiarized to many technological solutions and I searched new suppliers for my own practices... persons with skills, new knowhow... And well, there was always like that. Dream that someday I will establish an own software company in North America..." (Mike)

When Mike was offered the possibility of developing a spin-off from the project in the spring of 2012, he mentioned that it was the change required to fulfill a long-held 
dream. Thus, the offer was difficult to refuse, even though his employment in the MNE was not in immediate danger. For Tom, the reasons were quite different. He had experienced the drawbacks of working in the MNE as an employee and found that the working style that he preferred was no more possible:

"Of course I like, doing something, being part in a big corporation you spend your time with politics and your managerial stuff than actually doing. Creating new stuff, or... just work. Enjoying your work and go to enjoy it, not just discussing all the time and create all kind of problems there. These are the main reasons why I left the MNE." (Tom)

Nevertheless, the connecting factor for both individuals was their strong commitment to the opportunity in which they had invested for 2 years. For instance, Tom describes his connection to the opportunity in the following words: "I'm always in love with WTC because it's more like my baby there. It also runs some algorithms that I was... invented, let's say, during my PhD studies..." (Tom). Similarly, Mike states that "I have these own... children. I say that I have four children with the MNE and I regard them with a great passion, like my children." (Mike).

The second phase of the opportunity emergence process represents findings similar to those existing in the first one (see Fig. 2). Furthermore, in this case there was an encounter of different knowledge domains (Corbett 2005; Eckhardt and Shane 2003; Hansen et al. 2011) which enabled switching of the opportunity to a mobile network solution. Moreover, as mentioned previously, this was linked to the encounter of technological and commercial knowhow, considered similar to the market and technological orientation described in the SO literature (Hakala 2011). However, the contextual findings differ significantly from the previous phase and thus provide new insights on the matter (Reuber et al. 2017). Although these findings were strongly related to the MNE, this did not support the development of innovation in the same way as before. Moreover, this time, the development of innovation followed the MNE's corporate strategy, which emphasized the mobile technology particularly. This was a major factor in switching the innovation into a mobile solution. In addition, this perception particularly reflected the commercial expertise of the individuals. However, the level of support by the MNE had collapsed at this point and thus the opportunity did not progress to the prototype stage as it had done previously. Nevertheless, the lack of support did not hinder the entrepreneurial orientation of the individuals who were at this point ready to continue with the opportunity independently. The findings of this article have been analyzed in more detail in the following section.

\section{Analysis and discussion}

The first part of the findings supports the notion that prior experience plays a significant role in the opportunity discovery process (Kraus et al. 2017). Moreover, this article advances our understanding about the antecedents of entrepreneurial opportunity (Kuckertz et al. 2017) by offering in-depth insights about how prior knowledge (George et al. 2016) and prior experience (Haynie et al. 2009) contribute to the 
opportunity emergence process. Firstly, the individual characteristics that drove the initial opportunity discovery and its subsequent development represented features related to the entrepreneurial orientation of SO. This was predominantly visible in the innovative (Hakala 2011) and proactive behavior (Hakala 2011; Kickul and Gundry 2002; Odorici and Presutti 2013) of the individuals. Hence, the entrepreneurial manner of working was central to both interviewees and was regarded as somewhat different from the normal practice in the MNE. For instance, as Tom describes his role, "The crazy doing different crazy things...you got to do that... But on the other hand, I was the crazy guy that has the crazy ideas" (Tom). Moreover, Mike had participated in similar independent projects several times before this event. Thus, the individuals seemed to possess the tendency to engage in innovations entrepreneurially even while working for an MNE. In addition, these findings are somewhat in agreement with those made in the field of IE. In this case, characteristics such as creativity, self-efficacy, the need for achievement, and the need for independence have been found to facilitate new firm emergence (George et al. 2016). These were all present in this study but differ from the previous research in the sense that they relate to the entrepreneurial opportunity and not to organization creation. Thus, it seems that entrepreneurial orientation and similar characteristics of the individuals are the key features in opportunity emergence. Hence, the entrepreneurial dimension deserves all the attention it has received so far and more in the fields of IE and SO.

The second part of the findings relates to the discussion on how opportunities come into existence. The chief cause for the same seems to be information-seeking behavior (Eckhardt and Shane 2003), active search behavior (Mainela et al. 2014), and alertness (Kuckertz et al. 2017) to market imbalances. In this case, the opportunity was mirrored from the beginning to match customer requirements and can be therefore be considered crucial to the process. Moreover, it was found that the reconciliation of the customer demands and suitability of innovation required a combination of commercial and technological knowhow. In this case, the commercial knowledge linked especially to Mike's expertise, who had an overall outlook of the industry and market interface within the telecommunication sector. However, the opportunity would not have reached the prototype stage without technological expertise. This involved Tom's competence as well as that of the rest of the team who had much more rigorous and hands-on knowledge about innovation at the product level. As Tom says of his role, "I know the whole product very well. Usually when there's a big problem, then I'm just trying to solve it or something like that." (Tom). These findings agree with the previous insights that entrepreneurial opportunities result from the interaction between individuals and the environment (Dimov 2011) and that entrepreneurial opportunities are discovered in situations where various knowledge domains meet (Hansen et al. 2011). However, the findings indicate that the ratio of environmental influence and the balance between the knowledge domains evolve over time. Firstly, what started from a very extensive realization of customer demands moved rapidly towards the development of a specific technological solution. Secondly, it appears that technological knowhow was the dominant dimension during the implementation of the opportunity. Hence, these findings support the perspective that opportunity discovery and creation are complementary processes (Renko et al. 2012). However, the findings are insufficient to elucidate whether discovery and creation are separate phases (Oyson and Whittaker 2015). Nevertheless, they do suggest that entrepreneurial opportunity development can 
be considered a longitudinal process that requires constant refinement. Thus, future studies are required to investigate the longitudinal development of entrepreneurial opportunities.

The third part of the findings is linked to the influence of the context. The following findings advance our understanding of how and why the context affects entrepreneurial opportunity (Reuber et al. 2017). In this case, the influence of the context was present from the very beginning as the government level initiative marked a starting point for the opportunity emergence during the observation period adopted in this study. Thus, the findings suggest that government level actors can influence the availability of opportunities not only with financial aid (Eckhardt and Shane 2003, p. 341) but by openly engaging in the technology discussion. Moreover, it seems that the individuals were actively following the technological development and regulation of their field. In this case, the most immediate context was the MNE linkage. What started almost as a startup-like activity transformed soon into a more careful development program chiefly due to the financial downturn that the MNE was facing soon after the innovation competition. This implied that it was nearly impossible to implement any new technology at that moment. The entire organization seemed to be in mental lockdown as no one was willing to be held accountable for any potential failure. Moreover, the MNE linkage seemed to impact the availability of knowledge. In this case, the team had an abundance of technological knowledge throughout the pre-launch period but seemed to lack the customer-related feedback. This was probably due to the fact that the opportunity was never fully implemented by the MNE. Hence, this finding supports the insight that access to information can be crucial for entrepreneurial opportunity development (Hayton and Cholakova 2012). However, this topic requires further study for a thorough understanding. Overall, it is anticipated that these findings will encourage researchers to consider the contextual features when investigating entrepreneurial opportunities in future studies.

\section{Conclusions}

The following conclusions emerge from this study. Firstly, it seems that the pre-launch period represents a significant prerequisite for entrepreneurial opportunity emergence. This links especially to the characteristics and skill of the individuals. In this case, it was found that an entrepreneurial orientation drove the opportunity discovery behavior and can thus be considered central to this process. Moreover, it was found that opportunity recognition fundamentally resulted from information-seeking behavior about market imbalances and ways to respond to them. Such a process required incorporation of commercial and technological knowledge domains which was also central to opportunity emergence and its subsequent development. Secondly, it was found that the context was a significant precondition for opportunity emergence. In the studied case, the most significant elements were linkage to the MNE and the level of support granted to the project.

Reflection upon the findings within the theoretical framework of this study offers several significant insights. Firstly, in relation to entrepreneurial opportunity theory, this study supports the notion that the pre-launch period is quite significant for innovation (Hewerdine and Welch 2013) which has been linked to entrepreneurial opportunity 
recognition in this study. Consequently, the findings support the insights that the prior experience (Haynie et al. 2009) and knowledge (George et al. 2016; Kuckertz et al. 2017) support opportunity recognition and should therefore be included in the equation. Moreover, this article provides new insights as to why this is so. In this case, an essential feature was the intersection of technological and commercial knowhow which enabled the emergence and subsequent development of the opportunity. This finding supports the insight that contrasting knowledge domains (Hansen et al. 2011) and knowledge asymmetries (Corbett 2005; Eckhardt and Shane 2003) contribute to the opportunity discovery process. In addition, the findings can be linked to the discovery and creation debate (see: George et al. 2016; Suddaby et al. 2015). The findings of this study support the supplementary insight of the matter (Renko et al. 2012) and the perspective that the emergence of opportunities occurs in the interaction between individuals and the environment (Dimov 2011). In addition, the SO perspective adopted in this study offers some very relevant and significant insights. On top of the list is the finding that entrepreneurial orientation can be conceived of as the primary dimension driving the innovation-seeking behavior of individuals (Hakala 2011; Kickul and Gundry 2002; Odorici and Presutti 2013). Moreover, the market and technological orientation of the individuals were present in the opportunity emergence process (Hakala 2011). Finally, there are findings that link to the discussion about the role of context (Reuber et al. 2017). These particularly reflect the institutional features and characteristics (1st dimension) and individual, firm, and institutional level events (3rd dimension) affecting the preconditions of entrepreneurial opportunity (Reuber et al. 2017).

\section{Limitations and future research}

The first limitation of this study is the fact that the findings are based on material involving one company and therefore over-generalization should be avoided. Secondly, the interview material was retrospective and limited to only two individuals, although this was complemented by applying follow-up interviews and email discussion with Mike. Moreover, the observation period concerned only the pre-launch period. Thus, based on the results of the study, it is not possible to comment on what happens to the opportunity once it meets the market. Thirdly, the findings should be viewed according to the context. In this case, the MNE attachment had a significant impact on the emergence of the entrepreneurial opportunity. However, the conditions for opportunity emergence can vary in different settings, for example in different industries and countries. Consequently, we need further research of other industries. Additionally, the research would benefit from real-time studies, focusing especially on what happens to entrepreneurial opportunities, when they are introduced to the market.

On the agenda for future research is the need for longitudinal investigation of how entrepreneurial opportunities develop over time. In this study, it was discovered that entrepreneurial opportunity had already changed during the pre-launch period. It is likely, therefore, that similar development will continue, for instance when the opportunity is introduced to the markets and starts to gain customer feedback. In this case, for instance, a learning-based study could be a practical alternative as it would allow us to investigate how opportunities are updated when more information is accumulated 
(McCann and Vroom 2015). Overall, the most significant utility of longitudinal studies on this topic would be the clarification of the discovery-creation debate (George et al. 2016; Suddaby et al. 2015). Already in this cross-sectional study, features pertaining to both perspectives were observed. It seems, in addition, that their significance changed with the development.

\section{Practical implications}

This article also offers practical implications for those interested. According to the findings, it seems that MNEs may provide an innovative environment, thereby supporting the recognition of entrepreneurial opportunities. Moreover, at least in this case, the MNE was ready to allow individuals to continue the project in a spin-off company. Hence, people employed by MNEs can also work in an entrepreneurial way. More importantly, individuals in similar situations could consider the spin-off option as one alternative to start their entrepreneurial careers. In addition, the recognition and development of entrepreneurial opportunities seems to require openness. Thus, entrepreneurs and entrepreneurs-to-be need to keep their minds open and to be ready to acquire feedback to recognize and develop entrepreneurial opportunities further. Accordingly, the interaction of various knowledge domains seems to be essential. Moreover, even though this research did not explore market contact, it can be expected that feedback becomes even more crucial when the innovation is launched. Thus, entrepreneurs, especially those operating in the high-technology sector, should be prepared to make (possibly major) modifications to the innovation based on market and customer preferences.

Funding information Open access funding provided by LUT University. The paper was financed by grants from the Foundation of Economic Education and Yksityisyrittäjäin Säätiö (A Private Entrepreneur Foundation). The author would like to thank these foundations for their kind support.

\section{Compliance with ethical standards}

Conflict of interest The author declares that he has no conflict of interest.

Open Access This article is distributed under the terms of the Creative Commons Attribution 4.0 International License (http://creativecommons.org/licenses/by/4.0/), which permits unrestricted use, distribution, and reproduction in any medium, provided you give appropriate credit to the original author(s) and the source, provide a link to the Creative Commons license, and indicate if changes were made.

\section{References}

Balodi KC (2014) Strategic orientation and organizational forms: an integrative framework. Eur Bus Rev 26(2):188-203

Bergh P, Thorgren S, Wincent J (2011) Entrepreneurs learning together: the importance of building trust for learning and exploiting business opportunities. Int Entrep Manag J 7(1):17-37

Cooper D, Peake W, Watson W (2016) Seizing opportunities: the moderating role of managerial characteristics on the relationship between opportunity-seeking and innovation efficacy in small businesses. J Small Bus Manag 54(4):1038-1058 
Corbett AC (2005) Experiential learning within the process of opportunity identification and exploitation. Enterp Theory Pract 29(4):473-491

Coviello N, Tanev S (2017) Initiating a new research phase in the field of international entrepreneurship: an interview with professor Nicole Coviello. Technol Innov Manag Rev 7(5):52-56

Dawson A, Hjorth D (2012) Advancing family business research through narrative analysis. Fam Bus Rev 25(3):339-355

Dimov D (2011) Grappling with the unbearable elusiveness of entrepreneurial opportunities. Enterp Theory Pract 35(1):57-81

Dyer WG Jr, Wilkins AL (1991) Better stories, not better constructs, to generate better theory: a rejoinder to Eisenhardt. Acad Manag Rev 16(3):613-619

Eckhardt JT, Shane SA (2003) Opportunities and entrepreneurship. J Manag 29(3):333-349

Eisenhardt K, Graebner M (2007) Theory building from cases: opportunities and challenges. Acad Manag J 50(1):25-32

Gartner WB (2007) Entrepreneurial narrative and a science of the imagination. J Bus Ventur 22(5):613-627

Gatignon H, Xuareb J-M (1997) Strategic orientation of the firm new product performance. J Mark Res 34(1):77-90

George NM, Parida V, Lahti T, Wincent J (2016) A systematic literature review of entrepreneurial opportunity recognition: insights on influencing factors. Int Entrep Manag J 12(2):309-350

Hakala H (2011) Strategic orientations in management literature: three approaches to understanding the interaction between market, technology, entrepreneurial and learning orientations. Int J Manag Rev 13(2):199-217

Hannibal M, Evers N, Servais P (2016) Opportunity recognition and international new venture creation in university spin-offs — cases from Denmark and Ireland. J Int Entrep 14(3):345-372

Hansen DJ, Lumpkin GT, Hills GE (2011) A multidimensional examination of a creativity-based opportunity recognition model. Int J Entrep Behav Res 17(5):515-533

Haynie JM, Shepherd DA, McMullen JS (2009) An opportunity for me? The role of resources in opportunity evaluation decisions. J Manag Stud 46(3):337-361

Hayton JC, Cholakova M (2012) The role of affect in the creation and intentional pursuit of entrepreneurial ideas. Entrep: Theory Pract 36(1):41-68

Hewerdine L, Welch C (2013) Are international new ventures really new? A process study of organizational emergence and internationalization. J World Bus 48(4):466-477

Jantunen A, Nummela N, Puumalainen K, Saarenketo S (2008) Strategic orientations of born globals - do they really matter. J World Bus 43(2):158-170

Kakapour S, Morgan T, Parsinejad S, Wieland A (2016) Antecedents of corporate entrepreneurship in Iran: the role of strategic orientation and opportunity recognition. J Small Bus Entrep 28(3):251-266

Kickul J, Gundry L (2002) Prospecting for strategic advantage: the proactive entrepreneurial personality and small firm innovation. J Small Bus Manag 40(2):85-97

Knight GA, Cavusgil ST (2004) Innovation, organizational capabilities, and the born-global firm. J Int Bus Stud 35(2):124-141

Kocak A, Carsrud A, Oflazoglu S (2017) Market, entrepreneurial, and technology orientations: impact on innovation and firm performance. Manag Decis 55(2):248-270

Kraus S, Niemand T, Angelsberger M, Mas-Tur A (2017) Antecedents of international opportunity recognition in born global firms. J Promot Manag 23(3):386-406

Kuckertz A, Kollmann T, Krell P, Stöckmann C (2017) Understanding, differentiating, and measuring opportunity recognition and opportunity exploitation. Int J Entrep Behav Res 23(1):78-97

Langley A (1999) Strategies for theorizing from process data. Acad Manag Acad Manag Rev 24(4):691-710

Mainela T, Puhakka V, Servais P (2014) The concept of international opportunity in international entrepreneurship: a review and a research agenda. Int J Manag Rev 16(1):105-129

Mccann BT, Vroom G (2015) Opportunity evaluation and changing beliefs during the nascent entrepreneurial process. Int Small Bus J 33(6):612-637

McGaughey S (2006) Reading as a method of inquiry: representations of the born global. Manag Int Rev 46(4):461-480

Odorici V, Presutti M (2013) The entrepreneurial experience and strategic orientation of high-tech born global start-ups: an analysis of novice and habitual entrepreneurs. J Int Entrep 11(3):268-291

Oviatt BM, McDougall PP (1994) Toward a theory of international new ventures. J Int Bus Stud 25(1):45-64

Oviatt BM, McDougall PP (2005) Defining international entrepreneurship and modeling the speed of internationalization. Entrep: Theory Pract 29(5):537-553

Oyson MJ, Whittaker H (2015) Entrepreneurial cognition and behavior in the discovery and creation of international opportunities. J Int Entrep 13(3):303-336

Phillips-McDougall P, Shane S, Oviatt BM (1994) Explaining the formation of international new ventures: the limits of theories from international business research. J Bus Ventur 9(6):469-487 
Presutti M, Odorici V (2018) Linking entrepreneurial and market orientation to the SME's performance growth: the moderating role of entrepreneurial experience and networks. Int Entrep Manag J. https://doi. org/10.1007/s11365-018-0533-4

Renko M, Shrader RC, Simon M (2012) Perception of entrepreneurial opportunity: a general framework. Manag Decis 50(7):1233-1251

Reuber AR, Dimitratos P, Kuivalainen O (2017) Beyond categorization new directions for theory development about entrepreneurial internationalization. J Int Bus Stud 48(4):411-422

Ruokonen M, Saarenketo S (2009) The strategic orientations of rapidly internationalizing software companies. Eur Bus Rev 21(1):17-41

Shane S, Venkataraman S (2000) The promise of entrepreneurship as a field of research. Acad Manag Rev 25(1):217-226

Suddaby R, Bruton GD, Si SX (2015) Entrepreneurship through a qualitative lens: insights on the construction and/or discovery of entrepreneurial opportunity. J Bus Ventur 30(1):1-10

Walsham G (1995) Interpretive case studies in IS research: nature and method. Eur J Inf Syst 4(2):74-81

Welch C, Piekkari R, Plakoyiannaki E, Paavilainen-Mäntymäki E (2011) Theorising from case studies: towards a pluralist future for international business research. J Int Bus Stud 42(5):740-762

Publisher's note Springer Nature remains neutral with regard to jurisdictional claims in published maps and institutional affiliations.

\section{Affiliations}

\section{Teemu Tuomisalo $^{1}$}

\section{Teemu Tuomisalo}

teemu.tuomisalo@student.lut.fi

1 School of Business and Management, Lappeenranta University of Technology, PL 20,

53851 Lappeenranta, Finland 